\title{
Effect of Setting of Performance Contract Objectives on Organizational Performance in the State Owned Sugar Companies
}

\author{
Mr. Andrew Opiyo Mwalim, Dr. Robert K.W. Egessa and Mr. Kwendo Evans \\ *Masinde Muliro University of Science and Technology, Kakamega, Kenya
}

Received 01 March 2019, Accepted 01 May 2019, Available online 02 May 2019, Vol.7 (May/June 2019 issue)

\begin{abstract}
Poor performance in the Kenya public sector consistently hindered the realization of sustainable economic growth and development since the country attained her independence in 1963 (Mbithi, 1996). Among the noted factors that contribute to poor performance included: excessive regulations and control, frequent political interference, poor management, outright mismanagement of resources and lack of a guiding vision (Government of Kenya, 2005). Lack of clear focus as to what is expected from employees and poor or no methods of measuring performance has been the greatest challenge (Muthaura, 2007). The new Government elected in 2003 decided to manage public service through performance contracting system to address the situation. In Kenya, Performance contracting concept can be traced back in 1990 through Cabinet Memorandum No. CAB (90) 35 when performance contracting paradigm was conceived and designed with an aim of having a real impact in changing the way things were being done, creating a new behavior patterns and adoption of positive attitude work ethics in the entire public service delivery (Kobia and Mohammed, 2006). The system was expected to return faith on government services to the citizens and other international stakeholders (Muthaura, 2007). The paradigm was later outlined in the Economic Recovery Strategy for Wealth and Employment Creation (ERS) 2003-2007.
\end{abstract}

Keywords: Performance contracting, objective setting, organizational performance

\section{The Concept of Performance Contracting}

Performance contracting is a branch of management science referred to as management control systems (GoK, Training Manual, 2005). Kumar (1994) defines performance contracting as a memorandum of understanding (MoU). In Kenya performance contracting is used as a management tool to help the public sector executives and policy makers to define responsibilities and expectations/ targets between the contracting parties to achieve common mutually agreed goals (Kobia and Mohamed, 2006). Different scholars have defined performance contracts differently. However, they seem to hold similar views on the contents of performance contracts. According to Blasi (2002), a performance contract is an agreement between two parties that clearly specifies their mutual performance obligations, intentions and responsibilities. It is a freely negotiated performance agreement between the government, acting as the owner of a government agency, and the agency itself up to and including other levels of management levels of the organization. Most commonly, performance contracts

*Corresponding author's ORCID ID: 0000-0000-0000-0000 DOI: https://doi.org/10.14741/ijmcr/v.7.3.1 include bonuses for a job well done, less often, salary decrease for poor performance. The increase interest in performance contracts coincides with the demands for greater accountability.

Nellis (1989) observes that performance contracts are negotiated agreements as owners of a public enterprise, and the enterprise itself in which the intentions, obligations and responsibilities of the two parties are freely negotiated and then clearly set out. Shirley (1998) advocates the view that performance contracts seem to be a logical solution since similar contracts have been successful in the private sector in shifting them from ex anti control to expose evaluation, thus giving managers the autonomy and incentives to improve efficiency and thereafter holding the managers accountable for results. Shirley and Xu (2000) observe that performance contracts are now widely used in developing countries where successful contracts have featured sensible targets, stronger incentives, longer terms, and managerial bonds but confined within competitive industries.

Mann (1995) and GoK(2005a) trace the evolution of performance contracting to France in the1970s when the French Prime Minister commissioned a committee headed by Simon Nora to investigate relations between public enterprises and the ministers. The concept was 
thereafter introduced in Franco-phone Africa in the 1980s in the National Railway in Senegal. Latin-American and Asia countries followed later in the same decade. Performance contracts are known by different countries as performance agreement; Memorandum of understanding; There are generally three types of performance contacts namely; the French system, the signaling system and the results based management. The French based system of performance contract does not allocate weights to targets. There is therefore no distinction between targets in terms of emphasis (by weighing them differently) and as such performance evaluation is affected by a highly degree of subjectivity. This system is practiced in France, United Kingdom, Senegal, China, Ivory Coast and Benin (Mann, 1995; Trivedi, 2005; GoK, 2005a).The Signaling System is based on the premise that public enterprise management should be appropriately guided to aim at improving real productivity and its efforts acknowledged and rewarded by an incentive system. It allocates weights and adopts a system of "five point" scale "criteria weights" which result in calculating of "composite score" or an index of performance of the enterprise. The system aims at motivating management to maximize return on the sunk capital. A performance contract is signed at the beginning of the year in which management is committed to improvement in real profitability. The system is practiced in Pakistan, Korea, Philippines, India, Bolivia and Gambia (Mann, 1995; Trivedi, 2005; GoK, 2005a).

Performance management is a systematic process of planning work and setting expectations, continually monitoring the performance, developing the capacity to perform and periodically rating performance. Results based management is one of performance management process. The concept involves formulation of outcomes and goals, selection of outcome indicators, setting of specific targets to reach and dates for reaching them, assessment of whether the targets have been met and analysis and reporting of results (Armstrong, 2003). The concept of results based management emphasizes the need for key internal and external stakeholders to be consulted and engaged in setting outcomes, indictors and targets. Whereas performance contracts focus on the outcome and results, result based management is a system that is used by the government agencies to achieve specified targets by focusing on inputs, processes and outcomes. Results based management is therefore a system that is used to mobilize the entire staff in an organization in achieving the agreed targets (Dessler, 2003).

In Kenya context a performance contract is a written agreement between the government and a state agency (local authority, state corporation or central government ministry) delivering services to the public, wherein quantifiable targets are explicitly specified for a period of one financial year (July to June) and performance measured against agreed targets. According to Blasi (2002), a performance contract is an agreement between two parties that clearly specifies their mutual performance obligations, intentions and responsibilities. The performance contracting practice hence mirrors very closely the OECD definition 'as a range of management instruments used to define responsibility and expectations between parties to achieve mutually agreed results'. Performance contract is freely negotiated performance agreement between Government, organization and individuals on one hand and the agency itself (Kenya, Sensitization Training Manual, 2004). It is an agreement between two parties that clearly specify their mutual performance obligations, and the agency itself.

\section{Setting of Objectives}

Setting appropriate objectives and making effective use of appraisals can improve organizational performance and also facilitate assessment of how well the employees are performing. Establishing clear defined objectives helps employees to focus on specific tasks and corporate goals. To monitor and asses how employees are performing, it is useful to set clear objectives with quantifiable performance. Involving staff in setting targets can ensure that they are more motivated to meet them and they identify better ways of carrying out the tasks. The benefits for defining performance targets include ensuring every employee contribution fits into the organization's goals, helping individual employees to understand their role and feel more valued, creating standards to measure quantity and quality of employees' work, and monitor performance of the Organization (Locke, 1968). Targets can also be viewed as an extreme form of management which all employees will not respond positively to. Performance appraisal includes activities to ensure goals are consistently being met in an effective and efficient manner. Performance management can focus on performance of the organization, department, product and employee.

Druker (1995) came up with the practice of management by objectives. He derived it as a principle of management aimed at harmonizing individual manager goals with those of the organization with a view to improve the overall performance. Management by objective enables management of the organization to concentrate their efforts on obtaining desired results from key areas of the business. It provides an opportunity for managers to collaborate in identifying key areas for results and establishing appropriate performance standards against which results can be measured. Ministry of Tourism services delivery standards and performance which are central to its mission have long been the concern of customers and this has affected quality of service delivery. Consequently delivery performance standards for Mail, Courier, financial and Agency services must be specific, measureable, achievable, realistic and time bound of paramount importance is that they meet the expectations of the customer on service delivery. 
Focusing on organization and individual activity through the use of targets linked to strategic aims can be a powerful tool but careful consideration needs to be given to what is targeted, how targets are applied and how targets are applied to (Ashton and Sung, 2005).

The process of setting goals should be a collaborative process between an employee and his or her manager. Whether writing long- or short-term goals, the most widely-used framework is SMART.

Specific: Well-defined to inform employees exactly what is expected, when, and how much. With specific goals, managers can easily measure progress toward goal completion.

Measurable: Provide milestones to track progress and
motivate employees toward achievement.

Attainable: Success needs to be achievable with effort by an average employee, not too high or too low to attain in the specified period as per the organization specific strategy.

Relevant: You should focus on the greatest impact to the overall company strategy.

Time-bound: Establish enough time to achieve the goal, but not too much time to undermine performance. Goals without deadlines tend to be overtaken by the day-to-day crises.

Goal alignment is critical for business success. It ensures that each person within your organization can see the direction for the business and know how their job fits in with the "Big Picture". To achieve goal alignment in your organization, you must first clearly communicate your strategic business objectives across the entire company. By allowing managers to access and view the goals of other departments, your organization can greatly reduce redundancy while finding better ways to support each other. With everyone working together toward the same objectives, your company can execute strategy faster, with more flexibility and adaptability. Essentially, goal alignment strengthens your leadership and creates organizational agility by allowing managers to: Focus employees' efforts on your company's most important goals; Understand more clearly all responsibilities associated with specific goals; and Strengthen accountability by assigning measurable, articulated goals visible company-wide.

Tracking Goals: Once you've established your company-wide and individual goals, the next step is tracking progress on those goals. It's important for employees to track their progress on goals because they need to have the information available during the allimportant review process. Additionally, managers need to be aware of progress on goals to step in with assistance or resources when it appears that goal targets will possibly be missed. Having this information handy is also helpful when management is not aware of all of the steps involved in reaching a goal and strong documentation assists you in discussions of past projects and successes when review time rolls around. Tracking your goals in a centralized location helps you stay on track in several ways: Organize, manage and reassess your goals frequently, Create action plans with milestones for larger goals, Track your time to make sure your daily efforts are focused on meaningful tasks.

Tools for Setting, Aligning and Tracking Company-wide Goals: What do you do when it's time to set goals quarterly or annually? What is the best way to track these goals? Goal software is the solution to make life easier for both employees and managers alike. This software is a valuable tool to communicate goals company-wide and hold people accountable for achieving those goals in support of the company's strategic plan. Employees can use the software when setting goals. They can use it to include smaller tasks and milestones that are basically landmarks on the way to the completion of longer-term goals with metrics to establish how success will be measured on the goal.

Goals can be cascaded from the top down and made visible to all; everyone within the company is now fully armed with the information necessary when setting goals. They can create individual goals that support company goals and link to others if the success of their goal is dependent upon the actions of a co-worker or manager in another department or location.

Finally, dashboards provide a snapshot of your progress on your goal setting based upon the target dates you and your manager have provided. The secret to effective goal setting and high performance: review your goals at least once a week or month to clarify your focus and use this information as a basis for goal performance discussions with your manager. You can use the opportunity to review the progress and adjust timelines or request additional resources if necessary or expand the goal once more information is gathered from other sources.

\section{Organizational Performance}

According to Armstrong and Baron (1998), performance management is a strategic and integrated approach to delivering sustained success to organizations by improving the performance of the people who work in them and by developing the capabilities of team'sand individual contributors. It supports the rationale that people and not capital provide organizations with a competitive advantage (Reynolds \&Ablett, 1998). The purpose of performance management is to transform the raw potential of human resource into performance by removing intermediate barriers as well as motivating and rejuvenating the human resource (Kandula, 2006). Competitive capacity of organization can be increased by building strong people and effectively managing and 
developing people (Cabrera \&Banache, 1999) which is in essence performance management. Bates \& Holton (1995) have pointed out that performance is a multidimensional construct, the measurement of which varies depending on a variety of factors (Armstrong, 2000). Amore comprehensive view of performance is achieved if it is defined as embracing both behavior and outcomes (Armstrong, 2000).

Employees' performance (EP) is an important factor that contributes to improve the outcomes, behavior and traits of the employees. It helps to improve the productivity of the organization. Nickols (2003) and Fort\&Voltero (2004) identify similar factor that are closely related and affect provider performance in the workplace. They include: clear goals and job expectations, suitable repertoire, immediate feedback, skills to perform, knowledge of the organizational structure, functional feedback system, sound metal models, sufficient motivation through self-satisfaction and incentives. As Waleed Ahmed Abdel-Razek (2011) mentioned, job performance is one of the most important activities that reflect both the goals and the means necessary to achieve it and represents the specialist efficiency or reaching the desired level of achievement in that work. It is the effort made by the employee within the organization in order to achieve a particular goal. The actual results that companies desire objectively measure. Effectiveness of job performance can, therefore, be achieved through six elements: planning, goal and objectives, organizing, decision making, individual abilities and characteristics.

Feedback mechanism must be put in place in order to improve organizational performance. Feedback is having the output of prior behavior communicated to an entity (employee, work group, or company) so that the entity may modify its current and future behavior to achieve desirable organization's goals. For the organization or its work unit's performance measurement is the link between decisions and organizational goals (Dye 1992). Measurement of organizational performance is the first step in improvement. But while measuring is the process of quantification, its effect is to stimulate positive action. The management should be aware that almost all measures have negative consequences if they are used incorrectly or in the wrong situation. Hence they have to study the environmental conditions and analyze these potential negative consequences before adopting performance measurement (GoK, 2004).

\section{Research Methodology}

The study adopted a descriptive survey study. The population of this study shall consist of 999 managers and supervisors of all the four public sugar companies who sign performance contracts. The sample 286 will be identified randomly from the employees who sign performance contracts from each of the 4 public factories namely, South Nyanza (SONY), Chemelil, Muhoroni and Nzoia. Both primary and secondary data will be used to generate information from respondents on views and opinions on information regarding the effect of performance contracting on organizational performance of all the four sugar companies. Secondary data will be obtained by use of literature from the company records. Documents are valuable source for empirical data collection (Charlesworth2003a).The documents include annual reports, NSC website, NSC annual work plan and NSC strategic plan 2012-2017.

\section{Research Findings and Discussion}

The study collected data from 207 respondents which constituted a response rate of $72.4 \%$. From the findings, $58.0 \%$ of the respondents were from Nzoia sugar, $12.1 \%$ from Sony sugar and $30.0 \%$ from Chemilil Sugar Respondents for the study were drawn from 3sugar manufacturing firms which is a representative sample of the study hence data collected from them is representative of the firms view of the issue that was being studied.

\section{Performance Contract Objectives and Targets}

From the findings in table 4.4 , the respondents agreed that they are involved in setting objectives for my PC (mean 3.70). They further agreed that PC objectives enables see the direction of our business (3.90). They also indicated that PC objectives are linked to the strategic plan (mean 3.88). The respondents also agreed that PC objectives are realistic (mean 3.68). They also indicated that Setting of objectives greatly affects organizational performance( mean 3.80).Performance measurement and target-setting area important to the growth process. While many small businesses can run themselves quite comfortably without much formal measurement or target - setting, for growing businesses the control these processes offer can be indispensable. This finding was similar to that of Messah \& Kariuki (2011) who found out in their study that $41 \%$ of respondents agreed that they were involved in setting PC targets. In the same vein 178 (84.4\%) of respondents agreed with the notion that PC had a link with EP, this implied that PC is largely considered by employees as having a positive impact on their performance, this was further confirmed by a response of (170) $80.6 \%$ who agreed that PC had enhanced EP. Furthermore, Omboi \& Kariuki (2011) found out that the introduction of performance based module, employees indicated that work environment in their areas had improved as they were able to work towards given targets. 
Table 4.1 Setting Objectives

\begin{tabular}{cccc}
\hline Setting objectives & N & Mean & Std. Deviation \\
\hline Am involved in setting objectives for my PC & 207 & 3.70 & 1.02 \\
PC objectives enables me see the direction of our business & 207 & 3.90 & 0.84 \\
PC objectives are linked to the strategic plan & 207 & 3.88 & 0.89 \\
PC objectives are realistic & 207 & 3.68 & 0.93 \\
Setting of objectives greatly affects organizational performance & 207 & 3.80 & 0.94 \\
\hline
\end{tabular}

Table 4.2 Organization Performance

\begin{tabular}{cccc}
\hline Organizational performance & N & Mean & Std. Deviation \\
\hline PC has greatly improved organizational performance & 207 & 3.53 & 0.98 \\
PC has the quality of service we offer to our customers & 207 & 3.71 & 3.15 \\
PC has reduced recurrent costs thus improved profits & 207 & 3.31 & 0.96 \\
PC has improved efficiency in our organization & 207 & 2.88 & 0.94 \\
PC has led to staff motivation & 207 & 0.97 \\
\hline
\end{tabular}

Source; Research study 2017

\section{Organization Performance}

From the findings in table 4.7, the respondents agreed that PC has greatly improved organizational performance mean 3.53), Further it was their view that PC the quality of service offered to our customers had improved by embracing PC (mean 3.71). It had reduced costs (mean 3.15), hence improved profits. PC had improved efficiency in organizations (mean 3.31) thus greatly improved organizational performance (mean 3.53) PC however had slightly led to staff motivation (mean 2.88). These findings reverberate the study done by Letangule and Leting (2012) who found out that with the introduction of performance contract in public institutions, there was enhanced value for money ( mean=3.0 and Std Dev.0.625), improved input/output (mean=4.00 and Std Dev.0.873) and reduced wastage ( mean=2.1 and Std Dev. $0.429)$. These findings are similar to findings of research conducted by Oluoch, Nyagol, \& Nyandiga, (2013) \& Opiyo (2009), Kubaison, (2014) and Ombong'o (2009). This also conforms to Mann (2010) who established that performance contracting had improved service delivery in majority of public sector involved. This is because performance inculcated a sense of accountability in the public servants who in turn worked hard and provided services to the public in a professional manner. Similarly, Ombong'o (2008); Kervasdone (2007) and Kobia \& Mohammed, 2006) observed performance contracting as a way of improving public service delivery. These findings agree with Muthaura (2007); who assert that performance contracting has gradually improved profitability in the Commercial State Corporations due to close focus of the customers. Further, Gatere, Keraro \& Gakure (2013) noted that productivity had increased productivity through the introduction of citizen service delivery charters in the Teachers Service Commission (TSC) due to refocused customers' needs. Similarly, Kobia \& Mohammed (2006) observed that performance improvements have been recognized in the National Customer Satisfaction Survey where the overall customer satisfaction index was 63.5.

\section{Correlation Results}

Pearson's product moment correlation analysis was used to assess the correlation between the variables.

$\mathrm{Ho}_{1}$ : Setting of performance contract objectives has no significant effect on organizational performance.

The results indicate that, there is positive significant correlation between Performance contract objectives and targets and organization performance $(r=0.445, p<$ 0.000, $n=207$ ) Since $P$ - value is < .0005, the null hypothesis was rejected and concluded that setting of performance contract objectives has significant effect on organizational performance.

\section{Summary}

The study found out that they are involved in setting objectives for my PC, PC objectives enables see the direction of our business, $P C$ objectives are linked to the strategic plan, PC objectives are realistic Setting of objectives greatly affects organizational performance as indicated by the mean scores of 3.70, 3.90, 3.88, 3.68 and 3.80 respectively. The hypothesis postulated that $\mathbf{H o}_{\mathbf{1}}$ : Setting of performance contract objectives has no significant effect on organizational performance. The null hypothesis was rejected and therefore concluded that setting of performance contract objectives has significance effect on organizational performance.

\section{References}

[1]. AAPAM, (2005). The Enabling State and the role of the Public Service in Wealth Creation: Problems and strategies for development in Africa. The Report of the $26^{\text {th }}$ Round table Conference of the African Association for Public Administration and Management Mombasa, Kenya.

[2]. Acton, T. and Golden, W. (2002). "Training: The way to retain valuable IT employees?" in Conference Proceedings, Informing Science, pp. $1-12$. 
[3]. Alvesson, $M$, understanding organizational structure, London: Sage Publications, 2002.

[4]. Anderson, E.W., and Sullivan, M.W., (1993), The antecedents and consequences of customer satisfaction firms, Marketing Science, Vol. 12, No. 2, pp. 241-268.

[5]. Anderson, E.W., Fornell, C., and Lehmann, D.R., (1994), Customer satisfaction, market share, and profitability; findings from Sweden, Journal of Marketing, Vol. 58, pp. 53-66.

[6]. Anderson, R.E. and Srinivasan, S.S., (2003), E-satisfaction and e-loyalty: a contingency framework, Psychology \&Marketing, Vol. 20, No. 2, pp. 123-138.

[7]. Andreassen, T. W., (1994), Satisfaction, Loyalty and Reputation as Indicators of Customer Orientation in the Public Sector, International Journal of Public Sector Management, Vol. 7, No. 2, pp. 16-34.

[8]. Andreassen, T.W., (1999), What Drives Customer Loyalty with Complaint Resolution? Journal of Service Research,Vol. 1, No. 4, pp. 324-332.

[9]. Andreassen, T.W., and Lindestad, B., (1998a), Customer Loyalty and Complex Services: The impact of corporate image on quality, customer satisfaction and loyalty for customers with varying degrees of service expertise, International Journal of Service Industry Management, Vol. 9, No. 1, pp. 7-23.

[10]. Andreassen, T.W., and Lindestad, B., (1998b), The Effect of Corporate Image on in the Formation of CustomerLoyalty, Journal of Service Research, Vol. 1, No. 1, pp. 82-92.

[11]. Antonides, G., Verhoef, P.C., and Aalst, M.V., (2002), Consumer Perception and Evaluation of Waiting Time: AField Experiment, Journal of Consumer Psychology Vol. 12, No. 3, pp. 193-202.

[12].Armstrong, M. (2006): Performance Management: Key Strategies and Practical. Guidelines, (3rd edition) Kogan Page Ltd, London.

[13]. Audrestsch, D.B. "Small firms and efficiency," in Z.L. Acs, (ed.), Are small firms important? Their role and impact. Boston MA: Kluwer Academic Publishers, 1991, 21-38.

[14]. Aviz ienis, A., Laprie, J. C. and Randell, B., (2001), Fundamental Concepts of Dependability, Newcastle University Report no.CS-TR-739.

[15]. Bergh, D. D. and Holbein, G. F. (1997), Assessment and redirection of longitudinal analysis: demonstration with a study of the diversification and divestiture relationship, Strategic Management Journal, Vol. 18, No. 7, pp. 557-571.

[16]. Berry, L.L., (1995), Relationship Marketing of ServicesGrowing Interest, Emerging Perspectives, Journal of the Academy of Marketing Science, Vol. 23, No. 4, pp. 236-245.

[17]. Bielen, F., and Demoulin, N., (2007), Waiting time influence on the satisfaction-loyalty relationship in services, Managing Service Quality, Vol.17, No. 4, pp. 174-193.

[18]. Barrier, M., "Re-engineering your company," Nation's Business, 82, 2, 1994, $16-28$.

[19]. Buckley, R. and Caple, J. (2000), The Theory and Practice of Training, KoganPageLtd. 4th Edition.

[20]. Belcourt, M., Wright, P.C. and Saks, A.M. (2000). "Managing performance throughtrainingand development," in Nelson

[21]. Charles N. Greene, Everett, E. Adam, Jr. Ronald, J. Ebert (1980) management for effective performance prentice Hall, Iric. Englewood Cliffs NJ07632 also page 207.

[22]. Charlesworth, J., Lawton. Lewis, J., Martin, V, \& Taylor, P. 2003, Toolkit 1: study guide for MBA B713.Milton Keynes: Open University.
[23].Christina G. Chi, DoganGursoy., (2009). Employee satisfaction, customer satisfaction and financial performance, An empirical examination. International Journal of Hospitality Management 28 (2009) 245-253.

[24].Clemmer, Jim 2003. Organization structure limits or liberates high performance. Available interne thttp://www.clemmer.Net/excerpts/pf-orglimits.htm1.

[25]. Christensen, L.B 2004 Experimental methodology $9^{\text {th }}$ edUSA Allyn and Bacon inc.

[26]. Creswell, W. (2012).Educational research: Planning, conducting, and evaluating quantitative and qualitative research. Upper Saddle River, NJ: Prentice Hall.

[27]. Cook, H. Dwilight DF, Gerald, RF, Michelle, M.A, Berkson, HM, (1998). Towards social contraxt theory of human resource management organization effectiveness relationship. Human Resource Management Review. Volume 8, issue 3.

[28]. D'Aveni, R., "Hyper competition: The Dynamics of strategic maneuvering", Basic Books, New York, NY Discussion Paper Series; Institute of Policy Analysis and Research, 1994.

[29]. Deal, T.E. \& Kennedy, A.A., 1982.Corporate cultures, Addison-Wesley Reading, MA.

[30]. Domberger, S.(1994) "Public sector contracting: does it work?", The Australian Economic Review, 3rd qtr, pp. 9196.

[31]. Dessler,G. (2005) Human Resource Management: Pearson ,Prentice Hall,NewJersey.U.S.A

[32]. Domberger,S(1998), The Contracting Organization, New York,Oxford University Press.

[33]. Ducker,P.F" (1984), Management by Objectives and Self Control." In The Practice of Management(New York: Harper \& Ro).

[34]. Dye, (1992). Relative performance evaluation and project selection, journalof Accounting Research, Vol . 30 (1) (Spring ), PP 27-52.

[35]. Engler, B. (1999). Personality Theories.An Introduction. (5thed.). Houghton Mifflin Company: Boston.

[36]. Esaiasson, Y. (1993). Research Methods: A contemporary version, New York.

[37]. Grapiret, G. (1990) .Public Sector Performance Contracting in France, France.

[38].GOK, (2005).Recruitment and Training Guide Nairobi: Government Printer,Kenya.

[39].GOK (2010)Evaluation of the performance of public agencies for the financial year 2008/2009, Government printer, Nairobi.

[40]. Government of Kenya, (2004), Economic Survey 2004, Government Printer, Nairobi.

[41]. Jacqueline A-M. Coyle-Shapiro, Lynn M. Shore., (2007).Theemployee-organization relationship: Where do we go from here? Human Resource Management Review 17 (2007)166-179.

[42].Jody ZallKinsek and Ray Risk (2004).Ten Steps of a Result Based Monetary and Evaluation SystemWorld Bank, Washington DC.

[43].Jordan,Y. and Prinsloo,M. 2001. Grasping service marketing. $1^{\text {st }}$ ed.Pretoria V\&R Printing Works.

[44].Judge, T.A., Ferris (1993), G.R., Social Context of Performance Evaluation Decisions, Academy of Management, 36 (1),80-105.

[45]. KorirP(2005) : The impact of performance contracting in state corporations. The case of East African Portll and Cement.An unpublished MBA project, University of Nairobi, Kenya. 
[46]. Habermas. (2005) Performance Contract and Management published MSA these Makerere University Uganda PP 50 56.

[47]. Hebert. A.Simon, (1967) Administrative Behaviour, $2^{\text {nd }}$ ed (New York :Macmillan Co.

[48]. Higgins, J.,"How effective companies operate: lessons from Japanese strategy", Creativityand Innovation Management, Vol. 4, No. 2, 1995

[49].Hunter, J.D, Gates, G.R (1998), " Outsourcing: 'functional', 'fashionable' or 'foolish'", in Griffin, G (Eds), Management Theory and Practice Moving to a New Era, Macmillan Education Australia Pty. Ltd., Melbourne,pp.133-44

[50].Islam, Nasir (1993). "Public Enterprise Reform: Management Autonomy, Accountability and Performance Contracts". Public Administration and Development 13(2): 129-52

[51]. Kaplan, Robert S. and David P. Norton (1996).Using the Balanced Scorecard as strategic management system.Harvard Business Review. Reprint 2012, www.hbr.org

[52]. Kandula, S. R. (2006). Performance management: In Performance management strategy intervention drivers. (1st ed.). (p. 5). Asoke K. Ghosh. 14.

[53]. Karia, N. and Ahmad, Z. (2000), "Quality practices that pay: Empowerment and teamwork," Malaysian Management Review, Vol. 35, No. 2, pp. $66-76$.

[54]. Kiboi, W., (2006), Management perception of performance contracting in state corporations.

[55]. An unpublished MBA project, University of Nairobi.

[56]. Kipyego.W.R (2011).The effect of performance contracting strategy on the performance of state corporations in the energy sector in Kenya. (unpublished thesis)

[57]. Kobia, Margaret \& N. Mohammed (2006).The Kenyan Experience with Performance contracting: African Association for Public Administration and Management $28^{\text {th }}$ AAPAM Annual Round table conference Seminar Paper, Arusha, Tanzania.

[58]. Kobia, Margaret \& Mohammed, (2006). The Kenyan Experience with Performance contracting: African Association for Public Administration and Management $28^{\text {th }}$

[59]. AAPAM Annual Round table conference Seminar Paper, Arusha Tanzania.

[60]. Kombo D. \& Tromo D. (2006). Proposal and Thesis Writing, Nairobi: Pauline"s publications Africa.

[61]. Korir P (2005): The impact of performance contracting in state corporations. The case of East African Portland Cement. An unpublished MBA project, University of Nairobi, Kenya.

[62]. Kothari, C.R. (2004). Research Methodology: methods and Techniques $2^{\text {nd }}$ Ed. New Delhi, WashuaPrakasha Publishers

[63]. Kubaison (2004) The Mediating Role of Employee Attitude on Participation- Performance Relationship in State owned Corporation in Kenya.International Journal of Research in social Sciences, 4 ( 3),19-36

[64]. Lam, K. and Kong, K. (1992), "A study on the effectiveness of in - house management training and development programmes," Malaysian Management Review, pp. $46-$ 55.

[65]. Lee, J.-N., Kim, Y.-G, , (1999)"Effect of partnership quality on is outsourcing: conceptual framework and empirical validation", Journal of Management Information Systems, Vol. 15, No. 4, pp. 29-61

[66].Letangule and Letting ( 2012 ) Effects of Performance Contract on Organiation Performance. The case of Kenya's
Ministry of Education. International Journal of Management and Busiess Studies, 2( 3),29-39.

[67].Liernert, I. (2003) "Civil Service Reforms in Africa: Mixed Results after 10 years".

[68]. Magee, K.C.(2002). The impact of organizational culture on the implementation of performance managemen $t$ (Doctoral dissertation. Available from dissertation and Theses database UMINO30477909).

[69]. Malathy (1997)."Performance contracting.A strategy for Public Enterprises. Reform in Sri Lanka?"Public Enterprise Reform and Regulatory Policy Series.IPS Publication. Research Journal of Finance and Accounting www.iiste.org ISSN 2222-1697 (Paper) ISSN 2222-2847 (Online) Vol.2, No 2, 2011

[70]. Mallon, Richard D. (1994) "State-owned Enterprises. Reform Through Performance Contracts. The case of Boliria". World Development 22(6): 925-34.

[71]. Mann, M. (2010). Make Millions and make Change!: Secrets to Business and Personal Success.USA, Makemillion. Com.

[72]. Martin, L. L. (2005). "Performance-Based Contracting for Human Services: Does It Work?," Administration in Social Work, Vol. 29(1). University of Central Florida.

[73]. Mbithi, P. (1996). Strategic Planning in the Public Service; Speech delivered during Senior Government officers at Mombasa

[74]. Mhuthia, Ngari and Mwangi (2012) Effectiveness of Performance Contracting in Public Institutions. A case Study of the Provincial General Hospita. International Journal of Science and Research, 3 (11), 1690-1695.

[75].Mckeown $M$,"The Truth about Innovation", Pearson, Financial Times, 2008.

[76]. Messah, O.B. \& Kariuki, F.K. (2011). "Factors Affecting Implementation of Performance Contract Initiative at Municipal Council of Maua- Kenya," Journal of Finance and Accounting VOL 2. No. 2

[77]. Mohamed, A.M (2009). The impact of performance contracting on organizational performance. A case of Kenya Revenue Authority.(unpublished thesis)

[78]. Mugenda O. and Mugenda A. (2003).Research Methods: Quantitative and Qualitative Approaches, Africa Centre for Technology Studies, Nairobi.

[79]. Mugwira (2014) Perfomance Contacting Implemantation and Employee Per formance in Embu Water and Sanitation Company Ltd, Embu County, Kenya . Research proposa. Nairobi Kenyatta University.

[80]. Musa P. Dlamini, (2001). “Contract Plans and Public Enterprise Performance" (Tangier, Morocco, 2001)

[81]. Muthaura, F. (2007).Performance Contracting in Kenya; Restoring Faith in government through Innovation to promote Quality of Public Service

[82]. Nyongesa, Sewe and Ng'arng'a (2012) Challenges Facing Implementation of Performance Contracts in State Corporations in Kenya. Research Journal in Organizational Psychology and Education Studies, 1( 5), 284-288.

[83]. O'Connor, B.N., Bronner, M. and Delaney, C. (1996), "Training for organizations, "Cincinnati, $\mathrm{OH}$ : Southwestern.

[84]. Obong'o Odhiambo, (2009). Historical Perspective of the Performance Contracting in Kenya

[85]. OECD (1999) Performance Contracts in the Public Sector.

[86]. Oluoch, Nyagol and Nyandiga (2013) Effects of Downsizing on Serving Employees of Dominion Farms in Siya County, Kenya. Business Management Dynamics Journal, 3, (6)

[87]. Omboi and Kamencu (2011) The Effects of Performance Appraisal Systems on Employees in Kenya. Tea 
Development Agency: A survey of selected Tea Factories in Meru County-Kenya, Journal of Finance and Accounting, 12(3), 16-34

[88]. Omboi B. M. Mucai P.G. (201 ) Factors Affecting the Implementation of Srategic Plans in Government Tertiary Institutions: European Journal of Business and Management, 3 (3), 85-105

[89]. Omboi, B M Kariuki, F.K., (2011).Factors Affecting Implementation of Performance Contract Initiative at Municipal Council of Maua-Kenya, Research Journal of Finance and Accounting www.iiste. Vol. 2, No 2.Kenya Methodist University.

[90]. Opiyo, H.(2006).Civil Service Reform Policy in Kenya: A review of the Retrenchment Strategy:Discussion Paper Series: Institute of Policy Analysis and Research. Nairobi.

[91]. Opondo (2004).A Survey of Strategic Planning and Performance of Public Corporations in Kenya. Unpublished MBA Project.

[92]. Parasuraman, A., Zeithaml, V.A. and Berry, L.L. (1988), SERVQUAL: a multiple-item scale for measuring consumer perceptions of service qualityll,Journal of Retailing, Vol. 64 No. 1 , pp. $12-40$

[93].Peterson (2005) Performance contract management in developing nations, published in Belgium.

[94]. Prajapati, T (2009) Performance Contracting in Kenya

[95]. Poh, J.P. (2001), TQM in Malaysia: A comparative study on employee"s perception of management practices in TQM and non-TQM companies, MBA unpublished thesis,UniversityTun Abdul Razak, Malaysia.

[96].PUMA/PAC (1999) and PBMSIG (2001)" Establishing an Integrated performance Measurement System". Performance Based Special Interest group.U.S. Department of Energy. U.S.A.

[97]. Rabindra,K (2005). Organizational Change. New York: The Free Press.

[98]. Rachel W.Y. Yee a, Andy C. L. Yeung T.C. Edwin Cheng, (2009).Republic of Kenya, (2005, Sensitization on performance contracts in the public sector, unpublished training manual.

[99]. Republic of Kenya. (2010)..Public Sector Reforms \& Performance Contracting Kenya, Office of the prime minister, Nairobi. Log Associates Ltd.

[100]. Rimmer C, Hall, , , S.J.,(1994)"Performance monitoring and public sector contracting", Australian Journal of Public Administration, Vol. 53, No. 4, pp. 453-61

[101]. Roest, H, Pieters, R, 1997"Thenomological net of perceived service quality", International Journal of Service Industry Management, Vol. 8, No. 4, pp. 336-51
[102]. Shirley, M. (1998). Public Policy for Private Sector; "Why performance contracts for state- owned enterprises haven't worked." Policy Research Working Paper 1769. World Bank, Development Research Group, Washington, D.C.

[103]. Steven P. Brown, Son K. Lam., (2008). A Meta-Analysis of Relationships Linking Employee Satisfaction to Customer Responses.Journal of Retailing 84 (3, 2008) 243-255.

[104]. Sureshchandar G, Rajendran C \&Anantharaman R. (2002).A holistic model for total quality service.International Journal of service industry management, 12(2), 378-412.

[105]. Thompson,A.A.Jr Stickland,A,J 111.\&Gamble,J.E(2007) Crafting and Executing Strategy.McGraw-Hill, NewYork.

[106]. Trivedi, Prajapati (1990), Memorandum of Understanding: An approach to improving Public Enterprise Performance, New Dechi:International Management Publishers.

[107]. Trivedi, P. (2007). 'Performance Contracts in Kenya: Instruments for Operationalizing Good Governance: World Bank (1995) Reforming State Enterprises The World Bank, New York.

[108]. Trochim,M. (2005). Research made easy,. Alaska, Alaska Publishing House Ltd.

[109]. Underdown, Ryan(2003).organizational structure. Available internet.edu/industrial/underdown/org.man/org structure. George.hrm.

[110]. Van Heerden, M.(2011).Personal communication.15 January -6April.

[111]. Walton, Richard E. (1988). A vision led approach to management restructuring. Organization Dynamics, spring 1986.vol 14.Issue 4, Pp 3- 17.

[112]. Wheeler, F. (2001, "A Bayesian approach to service level performance monitoring in supplier, provider relationship", The Journal of the Operational Research Society, Vol. 52 No. 4, pp,383-90.

[113]. Williams R. S. (2004), Performance Management: Perspectives on Employee in Developing Countries and in Countries with Economies in Transition London, International Thompson Business

[114]. Wolf. Danuiel (2002).Execution and structure. Available internet. http://www/dawatsioan.Garm/working \% 20 pairs- execution \% structure.htm.

[115]. World Bank (1995) Reforming State Enterprises, The World Bank, NewYork.

[116]. Zeithaml, V.A. and Bitner, M.J. (2000), Services Marketing: Integrating Customer Focus Across the Firm, New York; McGraw- Hill. 